\title{
THE STRUCTURE OF PRELITERACY COMPETENCE IN CHILDREN AGED FIVE TO SEVEN YEARS
}

\author{
IVANKA BIDER PETELIN ${ }^{1}$, MARTINA OZBIČ ${ }^{2}$ \\ 'Primary School of Venclja Perka Domžale, Preserje, Slovenia; contact: ivanka.bider@gmail.com \\ ${ }^{2}$ LOGOS Martina Ozbič, Sežana, Slovenia
}

Received: 26.04.2020.

Original research article

Accepted: 14.11.2020.

UDK: 81'232

81 ' $4-053.2$

doi: 10.31299/hrri.56.2.1

\begin{abstract}
Children's early literacy development is a key contributor to later literacy skills and overall academic achievement. We have developed a set of tests that assesses preliteracy competence based on well-established foreign and Slovenian instruments or tools. A sample of 307 children aged from five to seven years were tested. A high Cronbach alpha coefficient (alpha $=0.87)$ indicates that the design instrument is an internally reliable instrument. This paper showcases and describes the differences in the development of preliteracy competence in different age group. The results show that children between 5 and 7 show the greatest development of the abilities to discern the initial sound, to analyse the sound, to notice the removal of sounds or syllables from a meaningless word, and to recall words on a given phoneme. Exploratory factor analysis with oblimin rotation revealed that preliteracy competence is best understood as a four-dimensional construct among children aged five to seven years. The first dimension is defined by higher-level phonological awareness, verbal memory, and rapid automatic naming, so it is metaphonology. The second factor, named perceptual language structure, expresses macro-linguistic structure (syllable, rhymes) and discrimination of words that sound similar. The third factor, named vocabulary, is saturated mostly by syllable analysis, vocabulary and word comprehension. The fourth factor is visual processing and capturing, which enable storage and refreshing of non-verbal information and the discrimination of symbols. The differences in development of preliteracy competency indicate intervention in the following areas: phonological awareness, verbal short-term memory, visual processing (discrimination and short-term memory) and vocabulary knowledge.
\end{abstract}

Keywords: preliteracy competence, latent structure of preliteracy competence, early interventio

\section{INTRODUCTION}

Literacy development is a life-long process for every individual; however, the most important period in this development is early childhood. Acquiring well-developed preliteracy competence is a critically important developmental milestone for children. A large body of research highlights the importance of preliteracy competence for beginning to learn to read, and it is also known which factors have the most important role in learning to read.

Skilled readers can derive meaning from printed text accurately and efficiently. Research has shown that in doing so, they fluidly coordinate many component skills, each of which has been sharpened through instruction and experience over many years. H. Scarborough (2001) compares skilled reading to the many strands of a rope. Each strand represents a part of reading development that must be mastered and then woven tightly together so that the reader can be fluent, accurate and automatic. The Reading Rope consists of lower and upper strands. The word-recognition strands (phonological awareness, decoding, and sight recognition of familiar words) work together as the reader becomes accurate, fluent, and increasingly automatic with repetition and practice. Concurrently, the language-comprehension strands (background knowledge, vocabulary, language structures, verbal reasoning, and literacy knowledge) reinforce one another and then weave together with the word-recognition strands to produce a skilled reader. The strands of literacy are developed separately until they are brought together by increased skill and by 
instruction. In other words, to unlock comprehension of text, two keys are required-being able to read the words on the page and understanding what the words and language mean within the text. If a student cannot recognise words on the page accurately and automatically, fluency will be affected, and in turn, reading comprehension will suffer. Likewise, if a student has poor understanding of the meaning of the words, reading comprehension will suffer. Weakness in any strand can disrupt reading. The sections below will describe the importance of the elements that lead to accurate word recognition.

\section{Phonological processing}

Phonological processing plays an important role in the development of reading. Most of the attention directed towards reading difficulties has focused on variety deficits in the phonological domain, including problems in phonological awareness, phonological memory, and rapid automatic naming (Melby-Lervag, Lyster, \& Hulme, 2012). Wagner and Torgesen (1987) suggested that this broad construct of phonological processing consists of three separate but linked phonological abilities: phonological awareness, phonological short-term memory and rapid automatic naming.

Phonological awareness is the understanding that oral language (i.e. sentences, words, syllables) can be divided into smaller components and manipulated. Thus, sentences can be divided into words, words into syllables, and syllables into phonemes. Phonemes are the smallest consciously distinguishable unit of spoken language (Torgesen \& Mathes, 2000). A wealth of studies has verified the predictive power of phonological awareness on reading achievement (e.g., Melby-Lervag, Lyster, \& Hulme, 2012), and children who experience difficulty with reading often have weak phonological awareness (Hogan, Catts \& Little, 2005; Landerl et al., 2013). Phonological awareness has proven to be important in the recognition and manipulation of sound and rhymes (Walcott, Scheemaker, \& Bielski, 2010). There are four types of phonological units within a word: the syllable, intrasyllablic-units of onset and rhymes, and finally the smallest phonological units, phonemes (Zigler \& Goswami, 2005). It is generally accepted that children with natural speech acquire rhyming ability before they develop aware- ness at the phoneme level (Goswami \& Brynat, 1990). Phonemic awareness is the ability to focus on and manipulate phonemes in speech, particularly segmentation and blending (Ehri, 2017).

Apart from phonological awareness, there is evidence that phonological memory is an important factor in reading acquisition (Gathercole \& Adams, 1994). It is known that many children with reading difficulties have deficits in the storage and/or retrieval of phonological information, and this makes it difficult for them to develop links between spoken words and orthographic spellings (Catts, 2017). Short-term memory is a separate, but related, construct that measures the capacity to maintain and process information (e.g. digits, pseudowords) for a short period of time (Siegel \& Linder, 1984; Stanovich, Cunningham, \& Feeman, 1984). A short-term memory for linguistic (verbal) material (e.g. a string of letters) is sometimes subsumed under phonological awareness, since both involve phonological processing, but there is evidence that it represents a distinct construct and accounts for unique variance in reading (Mann \& Liberman, 1984; Scarborough, 1998).

Rapid automatic naming is considered to be a measure of phonological processing as it measures the rapid retrieval of phonological codes from the lexicon. Rapid automatic naming is the ability to rapidly retrieve the name of familiar items visually presented in a serial array (e.g., objects, colours, numbers, or letters, or a combination of these in rapid alternating stimulus formats) (Denckla \& Rudel, 1976; Norton \& Wolf, 2012). Many studies have shown that rapid automatic naming is associated with literacy development, especially with reading speed (e. g. Georgiou \& Parrila, 2013), across languages (Georgiou, Aro, Lia, \& Parrila, 2016; Lervåg \& Hulme, 2009; Ziegler et al., 2010). As an explanation of the rapid automatic naming-reading relationship, rapid automatic naming was initially recognised as a measure of the speed of access to stored phonological information in long-term memory (Torgesen, Wagner, Rashotte, Burgess, \& Hecht, 1997). Rapid automatic naming and phonological awareness at all times affected reading, while the deletion of parts of the words better predicted the occurrence of learning difficulties in older students (Pan et al., 2011). Ziegler 
et al. (2010) demonstrated that after controlling statistically for children's phonological awareness, the association of rapid automatic naming to word reading was weak and limited only to fluency rather than to accuracy, across several alphabetic languages. Thus, they argued that the phonological component that rapid automatic naming shares with phonological awareness makes rapid automatic naming an important indicator of word reading (Pan et al., 2011). Performance on rapid naming tasks helps identify children with reading difficulties that cannot be attributed to phonological deficits (Parrilla \& Protopapas, 2017). Moreover, children with low rapid naming performance in addition to poor phonological awareness tend to be the poorest readers (Torpa et al., 2013) who likely benefit least from traditional interventions (Kirby, Georgiou, Martinussen, \& Parrila, 2010)

It has been debated for decades whether visual processing deficits are common in reading disorders and are related to reading ability in general. Accurate perception and reproduction of letters or words are important for visual discrimination (Pečjak, 1996). This means that the child is able to distinguish each individual character, as well as patterns or symbols (Magajna, Kavkler, Čačinovič Vogrinčič, Pečjak, \& Bregar Golobič, 2008). The type of visual processing affected is also debated, although visual discrimination and visual shortterm memory may be more commonly related to reading (Kibby et al., 2015). Many studies (Ortiz et al., 2014, Woodrome \& Johnson, 2009) have been conducted to evaluate the extent to which visual discrimination plays a role in developing letter identification abilities, which are essential in learning to read. Results from a correlational analysis (Woodrome \& Johnson, 2009) of four- and five-year-olds revealed a significant association between visual discrimination and letter identification abilities, which was not moderated by estimated nonverbal or verbal abilities or lexical access. Stronger visual discrimination abilities were also positively associated with better phonemic awareness skills, presumably because of the association between letter knowledge and phonemic skills, or letter-sound correspondence. Kibby et al. (2015) found that visual processing might be intact in reading disabilities when measured with tasks of untimed discrimination and visual short-term memory that do not require sequential processing or allow easy labelling.

The results of numerous studies (e.g. Al-Otaibi \& Fuchs, 2006; Lei et al., 2011, Ziegler et al., 2010) suggest that vocabulary knowledge, which is seldom recognised as a unique predictor of reading competence, emerged as a relatively important predictor of later reading abilities. Early deficits in the development of oral language are often associated with subsequent difficulties in learning to read (Catts, 2017). Some studies have taken a developmental approach and have shown a strong link between early oral language abilities and reading comprehension (Catts \& Adlof, 2011; Kendeou, van den Broek, White, \& Lynch, 2009), whereas others have provided support for an indirect route through listening comprehension (Kim \& Wagner, 2015).

Relevant literature (Batson - Magnuson, 2010; Catts, 2017; Carroll et al. 2016; Christoper et al., 2015) shows that there are numerous risk factors for later reading difficulties. The focus is on phonological processing (i.e. phonological awareness, verbal short-term memory and rapid automatic naming) as well as on visual processing (visual discrimination, visual short-term memory) and vocabulary knowledge.

\section{PURPOSE AND AIM OF THE RESEARCH}

We designed a battery of tests that assess preliteracy competence in children aged 5 to 7 years. With our study, we wanted to find out whether there are differences in the development of preliteracy competence between younger and older groups of children. The main aim of the research was to define the latent structure of preliteracy competence of children aged 5 to 7 years and, on that basis, indicate intervention.

\section{METHODS}

\subsection{Participants}

The sample consisted of 307 children who were attending the last year of kindergarten and the first year of primary school (155 boys and 152 girls). The age of the children ranged from 5 to 7 years. 
Table 1 shows the proportions of children in four age groups. In the sample, we did not include children with special needs who were receiving special educational services.

Table 1. Proportion of children by age and gender.

\begin{tabular}{|c|c|c|c|}
\hline $\begin{array}{c}\text { Age } \\
\text { group }\end{array}$ & $\begin{array}{c}\text { Number of } \\
\text { children }\end{array}$ & $\begin{array}{c}\text { Number of } \\
\text { boys }\end{array}$ & $\begin{array}{c}\text { Number of } \\
\text { girls }\end{array}$ \\
\hline $5.0-5.5$ & 58 & 31 & 27 \\
\hline $5.6-6.0$ & 78 & 39 & 39 \\
\hline $6.1-6.5$ & 85 & 41 & 44 \\
\hline $6.6-7.0$ & 86 & 44 & 42 \\
\hline Total & 307 & 155 & 152 \\
\hline
\end{tabular}

\subsection{Instruments}

\section{Test of preliteracy competence}

We have developed a test of preliteracy competence based on well-established foreign and Slovenian instruments or tools that include variables related to literacy. The designed instrument includes a cognitive profiling system (COPS) (Singelton, Thomas, \& Leedale, 1996), test of cognitive skills for preschool children (Prove di abilita cognitive per la Scuola dell'infanzia (PACSI) (Scalisi, Pelagaggi, Fanini, Desimoni, \& Romano, 2000), Test of phonological awareness (Magajna, 1996), special needs assessment profile (SNAP) (Weedon \& Reid, 2010), Acadia test of developmental abilities (Atkinskon et al., 1972) and bilingual aphasia test (BAT) (Paradis, 1987).

The test of preliteracy competence includes 16 subtests and covers seven dimensions of preliteracy abilities: a first level of phonological awareness (three subtests: identifying the rhymes, syllable synthesis and syllable analysis), a second level of phonological awareness (three subtests: identifying first sound, phoneme discrimination and phoneme analysis), a third level of phonological awareness (one subtest: syllable/phoneme deletion), rapid recall of verbal information (two subtests: rapid automatic naming and recalling words), auditory short-term memory (three subtests: auditory shortterm memory with visual support, auditory shortterm memory for digits and auditory short-term memory for sentences), visual abilities in discrimination and memory (three subtests: visual discrimination, short-term visual memory and short-term visual-spatial memory) and vocabulary (one subtest: vocabulary and word comprehension).

Table 2 shows a list of dependent variables and description of the measurement.

The reliability of the test of preliteracy competence was tested with Cronbach's alpha coefficient. The entire test of preliteracy competence showed good reliability: Cronbach's alpha coefficient was 0.87 . Reliability of dependent variables was good, except the speed of visual discrimination and recalling the words on a certain term, where the person coefficient of discrimination was very low $(\mathrm{r} \leq 0.20)$, so we eliminated these two variables from further analysis.

\subsection{Procedure of collecting data and the processing of data}

We collected data for the study from January to March 2014 and from February to May 2015 in different departments of kindergartens and elementary schools. Managers, teachers, educators, and parents of children were informed about the study and parental consent was obtained. All testing of children was held individually in two sessions (on different days), both times for about 20 minutes. Testing was carried out by a qualified person.

Data were entered and analysed using the Statistical Package for Social Sciences (SPSS-23). We used the following statistical methods: descriptive statistics to describe the sample, data display (arithmetic mean, standard deviation, minimum value, maximum value, percentiles), Cronbach's alpha coefficient for calculating the reliability of the test, the F-test to calculate statistically significant differences between younger and older groups of children, and factor analysis to determine the latent structure of all manifest variables in the test of preliteracy competence.

\section{RESULTS}

\section{4..1 Descriptive statistics}

Table 3 shows some of the parameters of descriptive statistics for dependent variables. Also calculated were arithmetic mean (M), standard deviation (SD), minimum (MIN), maximum (MAX) and percentile values $\left(25^{\text {th }}, 50^{\text {th }}\right.$, and $\left.75^{\text {th }}\right)$. 
Table 2. Description of dependent variables.

\begin{tabular}{|c|c|c|}
\hline $\begin{array}{l}\text { Dependent } \\
\text { variables }\end{array}$ & \begin{tabular}{l|} 
Symbols for \\
variables
\end{tabular} & Description of the measurement \\
\hline \multicolumn{3}{|c|}{ Subtests of preliteracy competence } \\
\hline \begin{tabular}{l|l|l}
$\begin{array}{l}\text { Identifying the } \\
\text { rhymes }\end{array}$ & \\
\end{tabular} & IDRHYM & $\begin{array}{l}\text { The child is given four words introduced with pictures. Only one word rhymes with the middle one. } \\
\text { The child needs to find the word. The maximum score is } 10 \text { points. The subtest includes } 10 \text { items. }\end{array}$ \\
\hline Syllable synthesis & SYNSYL & $\begin{array}{l}\text { Whilst listening, the child puts syllables into one word and pronounces it. The subtest } \\
\text { includes } 10 \text { items: } 3 \text { words with two syllables, } 4 \text { words with three syllables and } 3 \text { words with } \\
\text { four syllables. The maximum score is } 10 \text { points. }\end{array}$ \\
\hline Syllable analysis & ANALSYL & $\begin{array}{l}\text { The child divides each word into syllables. The subtest includes } 10 \text { items: } 1 \text { word has one } \\
\text { syllable, } 4 \text { words have two syllables, } 3 \text { words have three syllables and } 2 \text { words have four } \\
\text { syllables. The maximum score is } 10 \text { points. }\end{array}$ \\
\hline $\begin{array}{l}\text { Identifying the first } \\
\text { sound }\end{array}$ & IDFSOUND & $\begin{array}{l}\text { The child must choose from the one of four pictures that matches in the first sound with the } \\
\text { picture presented above. The subtest includes } 10 \text { items. The maximum score is } 10 \text { points. }\end{array}$ \\
\hline $\begin{array}{l}\text { Phoneme } \\
\text { discrimination }\end{array}$ & PHONDIS & $\begin{array}{l}\text { The subtest includes } 10 \text { items. Words are introduced with pictures. Then a fox and bear } \\
\text { appear successively, and they try to repeat each word. The child must tell which animal } \\
\text { correctly repeats the presented word. The maximum score is } 10 \text { points. }\end{array}$ \\
\hline Phoneme analysis & PHONANAL & $\begin{array}{l}\text { The child must divide given words into phonemes. The subtest contains } 10 \text { items: } 5 \text { words } \\
\text { with one syllable and } 5 \text { words with two syllables. The maximum score is } 10 \text { points. }\end{array}$ \\
\hline $\begin{array}{l}\text { Syllable/phoneme } \\
\text { deletion }\end{array}$ & $\begin{array}{l}\text { DELSYPH } \\
\text { DELSY } \\
\text { DELPH }\end{array}$ & $\begin{array}{l}\text { The child is told a word without meaning and also told which syllable or phoneme should be } \\
\text { removed. The subtest includes } 10 \text { items: } 4 \text { items from which a syllable needs to be removed, } \\
\text { and } 6 \text { items from which a phoneme needs to be removed. The maximum score is } 10 \text { points. }\end{array}$ \\
\hline $\begin{array}{l}\text { Visual } \\
\text { discrimination: } \\
\text { speed } \\
\text { accuracy }\end{array}$ & $\begin{array}{l}\text { VISDISS } \\
\text { VISDIDA }\end{array}$ & $\begin{array}{l}\text { From the } 84 \text { symbols, the child must find all symbols that are identical to the } 2 \text { given } \\
\text { symbols. Speed and accuracy are important in solving: how many symbols can the child } \\
\text { process in one minute, and how many lines are adequately resolved. }\end{array}$ \\
\hline $\begin{array}{l}\text { Short-term } \\
\text { auditory memory } \\
\text { with visual support }\end{array}$ & STAMVS & $\begin{array}{l}\text { For each group of animals, the child is told in what order they arrived at their destination. } \\
\text { From five animals, the child chooses the appropriate animals and places them in the } \\
\text { appropriate order on the podium. The subtest comprises one series of two animals, one } \\
\text { series of three animals, and one series of four animals. The maximum score is } 6 \text { points. }\end{array}$ \\
\hline $\begin{array}{l}\text { Auditory short- } \\
\text { term memory } \\
\text { - digits }\end{array}$ & AUSTMD & $\begin{array}{l}\text { We pronounce a certain sequence of numbers in a row and the child must repeat the sequence } \\
\text { in the same order. The subtest includes } 6 \text { items: } 3 \text { sequences with three numbers, } 2 \text { sequences } \\
\text { with four numbers, and one sequence with five numbers. The maximum score is } 10 \text { points. }\end{array}$ \\
\hline $\begin{array}{l}\text { Auditory short- } \\
\text { term memory } \\
\text { - sentences }\end{array}$ & AUSTMS & $\begin{array}{l}\text { The child hears sentences. For every sentence, there must be a reply, true or false. After } \\
\text { a set of sentences, the last word from every sentence must be repeated in the appropriate } \\
\text { sequence. The subtest includes } 2 \text { sets with two sentences, and the same number of sets with } \\
3 \text { sentences. The maximum score is } 10 \text { points. }\end{array}$ \\
\hline $\begin{array}{l}\text { Short-term visual } \\
\text { memory }\end{array}$ & STVISM & $\begin{array}{l}\text { After being shown a specific symbol, the child needs to circle from the set of symbols the } \\
\text { one that he saw. Difficulty increases with the increasing number of symbols shown (from } \\
\text { one to three) and the length of the set of symbols that he or she chooses. For every sequence, } \\
\text { there are two examples. Altogether there are } 6 \text { items. The maximum score is } 12 \text { points. }\end{array}$ \\
\hline $\begin{array}{l}\text { Short-term } \\
\text { visual-spatial } \\
\text { memory }\end{array}$ & STVSM & $\begin{array}{l}\text { A computer presentation shows the route of a mouse. The child links the holes in the } \\
\text { appropriate order. The difficulty increases with the length of the route of the mouse. At first } \\
\text { it makes its way to only one point, then in the eighth test, it goes to four points. Every stage } \\
\text { of difficulty has two tasks. Altogether, there are } 8 \text { items. The maximum score is } 20 \text { points. }\end{array}$ \\
\hline $\begin{array}{l}\text { Rapid automatic } \\
\text { naming }\end{array}$ & RAN & $\begin{array}{l}\text { The child must find five different objects, which are in different sequences and divided into } \\
6 \text { rows ( } 30 \text { subjects repeated many times), as quickly as possible; the child must also name } \\
\text { all objects exactly. Meanwhile, the time is measured (in seconds). }\end{array}$ \\
\hline $\begin{array}{l}\text { Recalling the } \\
\text { words on: } \\
\text { - a certain phoneme } \\
\text { - a certain term }\end{array}$ & $\begin{array}{l}\text { REWPH } \\
\text { REWT }\end{array}$ & $\begin{array}{l}\text { The child has } 1 \text { minute to name as many words as possible with the first letter P. In the } \\
\text { second part, the child has one minute to name all the foods he knows. Every word is scored } \\
\text { with } 1 \text { score. }\end{array}$ \\
\hline $\begin{array}{l}\text { Vocabulary and } \\
\text { word comprehension }\end{array}$ & VOCWC & $\begin{array}{l}\text { From four images, the child must choose one that fits the sentence he heard. The subtest } \\
\text { includes } 10 \text { items. The maximum score is } 10 \text { points. }\end{array}$ \\
\hline
\end{tabular}


Table 3. Some parameters of descriptive statistic for dependent variables.

\begin{tabular}{|l|c|c|c|c|c|c|c|}
\hline Variable & M & SD & MIN & MAX & 25th & 50th & 75th \\
\hline IDRHYM & 8.32 & 2.46 & 0.00 & 10.00 & 8.00 & 10.00 & 10.00 \\
\hline SYNSYL & 9.67 & 0.97 & 2.00 & 10.00 & 10.00 & 10.00 & 10.00 \\
\hline ANALSYL & 8.73 & 2.13 & 0.00 & 10.00 & 8.00 & 10.00 & 10.00 \\
\hline IDFSOUD & 7.85 & 2.51 & 0.00 & 10.00 & 6.00 & 9.00 & 10.00 \\
\hline PHONDIS & 9.20 & 1.24 & 0.00 & 10.00 & 9.00 & 10.00 & 10.00 \\
\hline PHONANAL & 5.93 & 4.30 & 0.00 & 10.00 & 1.00 & 8.00 & 10.00 \\
\hline DELSYPH & 2.57 & 3.11 & 0.00 & 10.00 & 0.00 & 1.00 & 5.00 \\
\hline DELPH & 1.65 & 2.03 & 0.00 & 6.00 & 0.00 & 0.00 & 3.00 \\
\hline DELSY & 0.90 & 1.26 & 0.00 & 4.00 & 0.00 & 0.00 & 2.00 \\
\hline VISDISS & 6.44 & 2.15 & 0.00 & 179.87 & 47.07 & 57.91 & 77.48 \\
\hline VISDISA & 4.10 & 2.55 & 0.00 & 7.00 & 2.00 & 5.00 & 6.00 \\
\hline STAMVS & 4.43 & 1.96 & 0.00 & 6.00 & 3.00 & 6.00 & 6.00 \\
\hline AUSTMD & 7.08 & 2.39 & 0.00 & 10.00 & 5.00 & 7.00 & 10.00 \\
\hline AUSTMS & 1.76 & 2.26 & 0.00 & 10.00 & 0.00 & 0.00 & 4.00 \\
\hline STVISM & 6.70 & 3.18 & 0.00 & 12.00 & 4.00 & 6.00 & 9.00 \\
\hline STVSM & 8.95 & 4.98 & 0.00 & 20.00 & 4.00 & 9.00 & 12.00 \\
\hline RAN & 4.46 & 11.71 & 21.70 & 92.70 & 36.80 & 42.30 & 48.70 \\
\hline REWPH & 2.90 & 2.80 & 0.00 & 16.00 & 1.00 & 2.00 & 5.00 \\
\hline REWT & 9.00 & 3.51 & 0.00 & 21.00 & 7.00 & 9.00 & 11.00 \\
\hline VOCWC & 7.63 & 1.55 & 1.00 & 10.00 & 7.00 & 8.00 & 9.00 \\
\hline
\end{tabular}

Table 3 shows that children tested for preliteracy competence best combined syllables into words (the average score was 9.7 points out of 10), and discriminated words that were similar (the average score was 9.2 out of 10). For both tasks, most of the children's scores were around the mean (standard deviations were 1.0 for syllable synthesis and 1.2 for phoneme discrimination). Percentile values showed that $75 \%$ of children aged 5 to 7 years reached all points at syllable synthesis. For variable phoneme discrimination, $50 \%$ of children reached all points. Similarly, half of the children reached all points at tasks that required identifying rhymes and analysing syllables. The results showed that children scored worst on the test of working memory, which requested repetition of the last words from 2-3 sets of sentences, and on the test of syllable/ phoneme deletion.

\subsection{Comparison of results by age}

Table 4 presents the variables that showed statistically significant differences across the four age groups.
Most of the variables demonstrated statistically significant differences according to age. The exceptions were syllable synthesis and analysis (data not shown).

Children between 5 and 7 showed the greatest development of abilities to discern the initial sound $(\mathrm{F}=21,00 ; \mathrm{p}=0,00)$, analyse phonemes $(\mathrm{F}=32,41$; $\mathrm{p}=0,00)$, remove syllables or phonemes from meaningless words $(\mathrm{F}=30,86 ; \mathrm{p}=0,00)$, and recall words from a given phoneme $(\mathrm{F}=25,51 ; \mathrm{p}=0,00)$. Significant differences across the four age groups of children were observed on the task of short-term auditory memory with visual support $(\mathrm{F}=14,38$; $\mathrm{p}=0,00)$, auditory short-term memory for sentences $(F=12,97 ; p=0,00)$, short-term visual memory $(\mathrm{F}=15,02 ; \mathrm{p}=0,00)$, short-term visual-spatial memory $(\mathrm{F}=14,46 ; \mathrm{p}=0,00)$, vocabulary and word comprehension $(\mathrm{F}=10,97 ; \mathrm{p}=0,00)$, accuracy of visual discrimination $(\mathrm{F}=17,01 ; \mathrm{p}=0,00)$, and rapid automatic naming $(\mathrm{F}=10,70 ; \mathrm{p}=0,00)$. Our research confirmed that there are statistically significant differences between younger and older groups of children on most tests of preliteracy competence, except syllable synthesis/analysis, recall of words from a certain term, and speed of visual discrimination. Children aged 5 to 6 years were as successful as children aged 6 to 7 in dividing words into syllables and in combining syllables into words. In addition, younger groups of children were just as successful as older ones in recalling the word from a certain term. We did not find statistically significant differences with age in speed of visual discrimination. Nevertheless, older children distinguished visually similar symbols more accurately, and they found identical symbols more rapidly. The survey confirmed that preschool children have, on average, less developed phonological skills. The children aged 6 or less were mostly successful on the subtests that measured syllable synthesis/analysis, rhyme identification, phoneme discrimination, and memorisation of a smaller set of auditory or visually presented symbols. Furthermore, children aged 5 to 6 are capable of distinguishing visually similar symbols, but still have difficulty distinguishing symbols that are differently oriented. As expected, our results showed that before the age of 7, children cannot autonomously remove a syl- 
Hrvatska revija za rehabilitacijska istraživanja 2020, Vol 56, br. 2, str. 1-18

Table 4. Results of the F-test to identify statistically significant differences according to age

\begin{tabular}{|c|c|c|c|c|c|c|}
\hline Variable & & Sum of squares & df & Mean square & $\mathbf{F}$ & Sig. \\
\hline \multirow[t]{2}{*}{ IDRHYM } & Between groups & 21.04 & 3.00 & 7.01 & 7.46 & 0.00 \\
\hline & Within groups & 284.96 & 303.00 & 0.94 & & \\
\hline \multirow[t]{2}{*}{ SYNSYL } & Between groups & 5.39 & 3.00 & 1.80 & 1.81 & 0.14 \\
\hline & Within groups & 300.61 & 303.00 & 0.99 & & \\
\hline \multirow[t]{2}{*}{ ANALSYL } & Between groups & 0.83 & 3.00 & 0.28 & 0.27 & 0.84 \\
\hline & Within groups & 305.17 & 303.00 & 1.01 & & \\
\hline \multirow[t]{2}{*}{ IDFSOUND } & Between groups & 52.67 & 3.00 & 17.56 & 21.00 & 0.00 \\
\hline & Within groups & 253.33 & 303.00 & 0.84 & & \\
\hline \multirow[t]{2}{*}{ PHONDIS } & Between groups & 23.14 & 3.00 & 7.71 & 8.26 & 0.00 \\
\hline & Within groups & 282.86 & 303.00 & 0.93 & & \\
\hline \multirow[t]{2}{*}{ PHONANAL } & Between groups & 74.34 & 3.00 & 24.78 & 32.41 & 0.00 \\
\hline & Within groups & 231.66 & 303.00 & 0.76 & & \\
\hline \multirow[t]{2}{*}{ DELSYPH } & Between groups & 71.56 & 3.00 & 23.85 & 30.83 & 0.00 \\
\hline & Within groups & 234.44 & 303.00 & 0.77 & & \\
\hline \multirow[t]{2}{*}{ DELPH } & Between groups & 72.95 & 3.00 & 24.32 & 31.62 & 0.00 \\
\hline & Within groups & 233.05 & 303.00 & 0.77 & & \\
\hline \multirow[t]{2}{*}{ DELSY } & Between groups & 44.80 & 3.00 & 14.93 & 17.32 & 0.00 \\
\hline & Within groups & 261.20 & 303.00 & 0.86 & & \\
\hline \multirow[t]{2}{*}{ VISDISA } & Between groups & 44.10 & 3.00 & 14.70 & 17.01 & 0.00 \\
\hline & Within groups & 261.90 & 303.00 & 0.86 & & \\
\hline \multirow[t]{2}{*}{ STAMVS } & Between groups & 38.13 & 3.00 & 12.71 & 14.38 & 0.00 \\
\hline & Within groups & 267.87 & 303.00 & 0.88 & & \\
\hline \multirow[t]{2}{*}{ AUSTMD } & Between groups & 10.59 & 3.00 & 3.53 & 3.62 & 0.01 \\
\hline & Within groups & 295.41 & 303.00 & 0.97 & & \\
\hline \multirow[t]{2}{*}{ AUSTMS } & Between groups & 34.83 & 3.00 & 11.61 & 12.97 & 0.00 \\
\hline & Within groups & 271.17 & 303.00 & 0.89 & & \\
\hline \multirow[t]{2}{*}{ STVISM } & Between groups & 39.61 & 3.00 & 13.20 & 15.02 & 0.00 \\
\hline & Within groups & 266.39 & 303.00 & 0.88 & & \\
\hline \multirow[t]{2}{*}{ STVSM } & Between groups & 38.32 & 3.00 & 12.77 & 14.46 & 0.00 \\
\hline & Within groups & 267.68 & 303.00 & 0.88 & & \\
\hline \multirow[t]{2}{*}{ RAN } & Between groups & 29.31 & 3.00 & 9.77 & 10.70 & 0.00 \\
\hline & Within groups & 276.69 & 303.00 & 0.91 & & \\
\hline \multirow[t]{2}{*}{ REWF } & Between groups & 61.71 & 3.00 & 20.57 & 25.51 & 0.00 \\
\hline & Within groups & 244.29 & 303.00 & 0.81 & & \\
\hline \multirow[t]{2}{*}{ VOCWC } & Between groups & 29.98 & 3.00 & 9.99 & 10.97 & 0.00 \\
\hline & Within groups & 276.02 & 303.00 & 0.91 & & \\
\hline
\end{tabular}

lable/phoneme from a word without meaning, or memorise the last words in 2-3 sets of sentences.

\subsection{The latent structure of preliteracy competence}

We used factor analysis to identify latent structure of the manifest variables on the test of preliteracy competence. According to the Kaiser criterion, we extracted four factors in factor analysis (Kaiser-Meyer-Olkin $=0.921$, Bartlett's test of sphericity: $\chi^{2}=1883.224, \mathrm{df}=136, \mathrm{p}=0.000$ ), which explained $57.03 \%$ of the total variance in the variables.

The first factor explained $37.6 \%$ of the variance. It was most saturated by the variables phoneme deletion, syllable deletion, recalling the words from a certain phoneme, phoneme analysis, auditory short-term memory for digits, auditory short-term memory for sentences, auditory short-term memory with visual support, identifying the first sound, and rapid automatic naming. Thus, the first factor is a 
Ivanka Bider Petelin, Martina Ozbič: The Structure of Preliteracy Competence in Children Aged Five to Seven Years

Table 5. Comparison of differences in average results between age groups

\begin{tabular}{|c|c|c|c|c|c|c|c|}
\hline \multirow[t]{2}{*}{ Dependent variable } & \multirow[t]{2}{*}{ (I) age } & \multirow[t]{2}{*}{ (J) age } & \multirow{2}{*}{$\begin{array}{c}\text { difference } \\
(I-J)\end{array}$} & \multirow[t]{2}{*}{ SE } & \multirow[t]{2}{*}{$\mathbf{p}$} & \multicolumn{2}{|c|}{$95 \%$ confidence interval } \\
\hline & & & & & & lower limit & upper limit \\
\hline \multirow[t]{12}{*}{ IDRHYM } & \multirow[t]{3}{*}{$5.0-5.5$} & $5.6-6.0$ & -0.20 & 0.17 & 0.63 & -0.63 & 0.23 \\
\hline & & $6.1-6.5$ & $-0.49 *$ & 0.17 & 0.02 & -0.91 & -0.06 \\
\hline & & $6.6-7.0$ & $-0.71 *$ & 0.16 & 0.00 & -0.13 & -0.28 \\
\hline & \multirow[t]{3}{*}{$5.6-6.0$} & $5.0-5.5$ & 0.20 & 0.17 & 0.63 & -0.23 & 0.63 \\
\hline & & $6.1-6.5$ & -0.29 & 0.15 & 0.24 & -0.68 & 0.11 \\
\hline & & $6.6-7.0$ & $-0.51 *$ & 0.15 & 0.01 & -0.90 & -0.11 \\
\hline & \multirow[t]{3}{*}{$6.1-6.5$} & $5.0-5.5$ & $0.49 *$ & 0.17 & 0.02 & 0.06 & 0.91 \\
\hline & & $5.6-6.0$ & 0.29 & 0.15 & 0.24 & -0.11 & 0.68 \\
\hline & & $6.6-7.0$ & -0.22 & 0.15 & 0.45 & -0.60 & 0.16 \\
\hline & \multirow[t]{3}{*}{$6.6-7.0$} & $5.0-5.5$ & $0.71 *$ & 0.16 & 0.00 & 0.28 & 1.13 \\
\hline & & $5.6-6.0$ & $0.51 *$ & 0.15 & 0.01 & 0.11 & 0.90 \\
\hline & & $6.1-6.5$ & 0.22 & 0.15 & 0.45 & -0.16 & 0.60 \\
\hline \multirow[t]{12}{*}{ IDFSOUND } & \multirow[t]{3}{*}{$5.0-5.5$} & $5.6-6.0$ & -0.37 & 0.16 & 0.09 & -0.78 & 0.04 \\
\hline & & $6.1-6.5$ & $-0.73 *$ & 0.16 & 0.00 & -0.14 & -0.33 \\
\hline & & $6.6-7.0$ & $-0.15^{*}$ & 0.16 & 0.00 & -0.56 & -0.75 \\
\hline & \multirow[t]{3}{*}{$5.6-6.0$} & $5.0-5.5$ & 0.37 & 0.16 & 0.09 & -0.04 & 0.78 \\
\hline & & $6.1-6.5$ & -0.36 & 0.14 & 0.06 & -0.73 & 0.01 \\
\hline & & $6.6-7.0$ & $-0.78^{*}$ & 0.14 & 0.00 & -0.15 & -0.41 \\
\hline & \multirow[t]{3}{*}{$6.1-6.5$} & $5.0-5.5$ & $0.73 *$ & 0.16 & 0.00 & 0.33 & 1.14 \\
\hline & & $5.6-6.0$ & 0.36 & 0.14 & 0.06 & -0.01 & 0.73 \\
\hline & & $6.6-7.0$ & $-0.42 *$ & 0.14 & 0.01 & -0.78 & -0.06 \\
\hline & \multirow[t]{3}{*}{$6.6-7.0$} & $5.0-5.5$ & $0.15^{*}$ & 0.16 & 0.00 & 0.75 & 1.56 \\
\hline & & $5.6-6.0$ & $0.78 *$ & 0.14 & 0.00 & 0.41 & 1.15 \\
\hline & & $6.1-6.5$ & $0.42 *$ & 0.14 & 0.01 & 0.06 & 0.78 \\
\hline \multirow[t]{12}{*}{ PHONDIS } & \multirow[t]{3}{*}{$5.0-5.5$} & $5.6-6.0$ & -0.29 & 0.17 & 0.31 & -0.72 & 0.14 \\
\hline & & $6.1-6.5$ & $-0.54 *$ & 0.16 & 0.01 & -0.97 & -0.12 \\
\hline & & $6.6-7.0$ & $-0.77 *$ & 0.16 & 0.00 & -1.19 & -0.34 \\
\hline & \multirow[t]{3}{*}{$5.6-6.0$} & $5.0-5.5$ & 0.29 & 0.17 & 0.31 & -0.14 & 0.72 \\
\hline & & $6.1-6.5$ & -0.26 & 0.15 & 0.33 & -0.65 & 0.14 \\
\hline & & $6.6-7.0$ & $-0.48^{*}$ & 0.15 & 0.01 & -0.87 & -0.09 \\
\hline & $6.1-6.5$ & $5.0-5.5$ & $0.54 *$ & 0.16 & 0.01 & 0.12 & 0.97 \\
\hline & & $5.6-6.0$ & 0.26 & 0.15 & 0.33 & -0.14 & 0.65 \\
\hline & & $6.6-7.0$ & -0.22 & 0.15 & 0.44 & -0.60 & 0.16 \\
\hline & $6.6-7.0$ & $5.0-5.5$ & $0.77 *$ & 0.16 & 0.00 & 0.34 & 1.19 \\
\hline & & $5.6-6.0$ & $0.48^{*}$ & 0.15 & 0.01 & 0.09 & 0.87 \\
\hline & & $6.1-6.5$ & 0.22 & 0.15 & 0.44 & -0.16 & 0.60 \\
\hline PHONANAL & $5.0-5.5$ & $5.6-6.0$ & -0.33 & 0.15 & 0.13 & -0.72 & 0.06 \\
\hline & & $6.1-6.5$ & $-0.81 *$ & 0.15 & 0.00 & -1.20 & -0.43 \\
\hline & & $6.6-7.0$ & $-1.33^{*}$ & 0.15 & 0.00 & -1.72 & -0.95 \\
\hline & $5.6-6.0$ & $5.0-5.5$ & 0.33 & 0.15 & 0.13 & -0.06 & 0.72 \\
\hline & & $6.1-6.5$ & $-0.48^{*}$ & 0.14 & 0.00 & -0.84 & -0.13 \\
\hline & & $6.6-7.0$ & $-1.00 *$ & 0.14 & 0.00 & -1.35 & -0.65 \\
\hline & $6.1-6.5$ & $5.0-5.5$ & $0.81^{*}$ & 0.15 & 0.00 & 0.43 & 1.20 \\
\hline & & $5.6-6,0$ & $0.48^{*}$ & 0.14 & 0.00 & 0.13 & 0.84 \\
\hline & & $6.6-7.0$ & $-0.52 *$ & 0.13 & 0.00 & -0.86 & -0.17 \\
\hline & $6.6-7.0$ & $5.0-5.5$ & $1.33 *$ & 0.15 & 0.00 & 0.95 & 1.72 \\
\hline & & $5.6-6.0$ & $1.00 *$ & 0.14 & 0.00 & 0.65 & 1.35 \\
\hline & & $6.1-6.5$ & $0.52 *$ & 0.13 & 0.00 & 0.17 & 0.86 \\
\hline
\end{tabular}


Hrvatska revija za rehabilitacijska istraživanja 2020, Vol 56, br. 2, str. 1-18

\begin{tabular}{|c|c|c|c|c|c|c|c|}
\hline \multirow[t]{12}{*}{ DELSYPH } & \multirow[t]{3}{*}{$5.0-5.5$} & $5.6-6.0$ & -0.17 & 0.15 & 0.67 & -0.57 & 0.22 \\
\hline & & $6.1-6.5$ & $-0.62 *$ & 0.15 & 0.00 & -1.01 & -0.24 \\
\hline & & $6.6-7.0$ & $-1.25^{*}$ & 0.15 & 0.00 & -1.64 & -0.87 \\
\hline & \multirow[t]{3}{*}{$5.6-6.0$} & $5.0-5.5$ & 0.17 & 0.15 & 0.67 & -0.22 & 0.57 \\
\hline & & $6.1-6.5$ & $-0.45^{*}$ & 0.14 & 0.01 & -0.81 & -0.09 \\
\hline & & $6.6-7.0$ & $-1.08 *$ & 0.14 & 0.00 & -1.44 & -0.73 \\
\hline & \multirow[t]{3}{*}{$6.1-6.5$} & $5.0-5.5$ & $0.62 *$ & 0.15 & 0.00 & 0.24 & 1.01 \\
\hline & & $5.6-6.0$ & $0.45^{*}$ & 0.14 & 0.01 & 0.09 & 0.81 \\
\hline & & $6.6-7.0$ & $-0.63^{*}$ & 0.13 & 0.00 & -0.98 & -0.28 \\
\hline & \multirow[t]{3}{*}{$6.6-7.0$} & $5.0-5.5$ & $1.25^{*}$ & 0.15 & 0.00 & 0.87 & 1.64 \\
\hline & & $5.6-6.0$ & $1.08^{*}$ & 0.14 & 0.00 & 0.73 & 1.44 \\
\hline & & $6.1-6.5$ & $0.63^{*}$ & 0.13 & 0.00 & 0.28 & 0.98 \\
\hline \multirow[t]{12}{*}{ DELPH } & \multirow[t]{3}{*}{$5.0-5.5$} & $5.6-6.0$ & -0.17 & 0.15 & 0.69 & -0.56 & 0.22 \\
\hline & & $6.1-6.5$ & $-0.67 *$ & 0.15 & 0.00 & -1.06 & -0.29 \\
\hline & & $6.6-7.0$ & $-1.26^{*}$ & 0.15 & 0.00 & -1.64 & -0.87 \\
\hline & \multirow[t]{3}{*}{$5.6-6.0$} & $5.0-5.5$ & 0.17 & 0.15 & 0.69 & -0.22 & 0.56 \\
\hline & & $6.1-6.5$ & $-0.51^{*}$ & 0.14 & 0.00 & -0.86 & -0.15 \\
\hline & & $6.6-7.0$ & $-1.09^{*}$ & 0.14 & 0.00 & -1.44 & -0.73 \\
\hline & \multirow[t]{3}{*}{$6.1-6.5$} & $5.0-5.5$ & $0.67 *$ & 0.15 & 0.00 & 0.29 & 1.06 \\
\hline & & $5.6-6.0$ & $0.51 *$ & 0.14 & 0.00 & 0.15 & 0.86 \\
\hline & & $6.6-7.0$ & $-0.58^{*}$ & 0.13 & 0.00 & -0.93 & -0.24 \\
\hline & \multirow[t]{3}{*}{$6.6-7.0$} & $5.0-5.5$ & $1.26^{*}$ & 0.15 & 0.00 & 0.87 & 1.64 \\
\hline & & $5.6-6.0$ & $1.09 *$ & 0.14 & 0.00 & 0.73 & 1.44 \\
\hline & & $6.1-6.5$ & $0.58^{*}$ & 0.13 & 0.00 & 0.24 & 0.93 \\
\hline \multirow[t]{12}{*}{ DELSY } & \multirow[t]{3}{*}{$5.0-5.5$} & $5.6-6.0$ & -0.13 & 0.16 & 0.84 & -0.55 & 0.28 \\
\hline & & $6.1-6.5$ & $-0.47 *$ & 0.16 & 0.02 & -0.88 & -0.07 \\
\hline & & $6.6-7.0$ & $-0.99 *$ & 0.16 & 0.00 & -1.40 & -0.58 \\
\hline & \multirow[t]{3}{*}{$5.6-6.0$} & $5.0-5.5$ & 0.13 & 0.16 & 0.84 & -0.28 & 0.55 \\
\hline & & $6.1-6.5$ & -0.34 & 0.15 & 0.09 & -0.72 & 0.04 \\
\hline & & $6.6-7.0$ & $-0.86^{*}$ & 0.15 & 0.00 & -1.23 & -0.48 \\
\hline & \multirow[t]{3}{*}{$6.1-6.5$} & $5.0-5.5$ & $0.47 *$ & 0.16 & 0.02 & 0.07 & 0.88 \\
\hline & & $5.6-6.0$ & 0.34 & 0.15 & 0.09 & -0.04 & 0.72 \\
\hline & & $6.6-7.0$ & $-0.52 *$ & 0.14 & 0.00 & -0.88 & -0.15 \\
\hline & \multirow[t]{3}{*}{$6.6-7.0$} & $5.0-5.5$ & $0.99 *$ & 0.16 & 0.00 & 0.58 & 1.40 \\
\hline & & $5.6-6.0$ & $0.86^{*}$ & 0.15 & 0.00 & 0.48 & 1.23 \\
\hline & & $6.1-6.5$ & $0.52 *$ & 0.14 & 0.00 & 0.15 & 0.88 \\
\hline \multirow[t]{12}{*}{ VISDISA } & \multirow[t]{3}{*}{$5.0-5.5$} & $5.6-6.0$ & $-0.44 *$ & 0.16 & 0.03 & -0.86 & -0.03 \\
\hline & & $6.1-6.5$ & $-0.60 *$ & 0.16 & 0.00 & -1.01 & -0.19 \\
\hline & & $6.6-7.0$ & $-1.10^{*}$ & 0.16 & 0.00 & -1.51 & -0.69 \\
\hline & \multirow[t]{3}{*}{$5.6-6.0$} & $5.0-5.5$ & $0.44^{*}$ & 0.16 & 0.03 & 0.03 & 0.86 \\
\hline & & $6.1-6.5$ & -0.16 & 0.15 & 0.71 & -0.53 & 0.22 \\
\hline & & $6.6-7.0$ & $-0.66^{*}$ & 0.15 & 0.00 & -1.03 & -0.28 \\
\hline & \multirow[t]{3}{*}{$6.1-6.5$} & $5.0-5.5$ & $0.60^{*}$ & 0.16 & 0.00 & 0.19 & 1.01 \\
\hline & & 5.6-6.0 & 0.16 & 0.15 & 0.71 & -0.22 & 0.53 \\
\hline & & $6.6-7.0$ & $-0.50^{*}$ & 0.14 & 0.00 & -0.87 & -0.13 \\
\hline & \multirow[t]{3}{*}{$6.6-7.0$} & $5.0-5.5$ & $1.10^{*}$ & 0.16 & 0.00 & 0.69 & 1.51 \\
\hline & & $5.6-6.0$ & $0.66^{*}$ & 0.15 & 0.00 & 0.28 & 1.03 \\
\hline & & $6.1-6.5$ & $0.50^{*}$ & 0.14 & 0.00 & 0.13 & 0.87 \\
\hline
\end{tabular}


Ivanka Bider Petelin, Martina Ozbič: The Structure of Preliteracy Competence in Children Aged Five to Seven Years

\begin{tabular}{|c|c|c|c|c|c|c|c|}
\hline \multirow[t]{12}{*}{ STAMVS } & \multirow[t]{3}{*}{$5.0-5.5$} & $5.6-6.0$ & -0.01 & 0.16 & 1.00 & -0.43 & 0.41 \\
\hline & & $6.1-6.5$ & $-0.57 *$ & 0.16 & 0.00 & -0.98 & -0.15 \\
\hline & & $6.6-7.0$ & $-0.81^{*}$ & 0.16 & 0.00 & -1.23 & -0.40 \\
\hline & \multirow[t]{3}{*}{$5.6-6.0$} & $5.0-5.5$ & 0.01 & 0.16 & 1.00 & -0.41 & 0.43 \\
\hline & & $6.1-6.5$ & $-0.56^{*}$ & 0.15 & 0.00 & -0.94 & -0.18 \\
\hline & & $6.6-7.0$ & $-0.80 *$ & 0.15 & 0.00 & -1.18 & -0.42 \\
\hline & \multirow[t]{3}{*}{$6.1-6.5$} & $5.0-5.5$ & $0.57 *$ & 0.16 & 0.00 & 0.15 & 0.98 \\
\hline & & $5.6-6.0$ & $0.56^{*}$ & 0.15 & 0.00 & 0.18 & 0.94 \\
\hline & & $6.6-7.0$ & -0.24 & 0.14 & 0.33 & -0.62 & 0.13 \\
\hline & \multirow[t]{3}{*}{$6.6-7.0$} & $5.0-5.5$ & $0.81 *$ & 0.16 & 0.00 & 0.40 & 1.23 \\
\hline & & $5.6-6.0$ & $0.80^{*}$ & 0.15 & 0.00 & 0.42 & 1.18 \\
\hline & & $6.1-6.5$ & 0.24 & 0.14 & 0.33 & -0.13 & 0.62 \\
\hline \multirow[t]{12}{*}{ AUSTMD } & \multirow[t]{3}{*}{$5.0-5.5$} & $5.6-6.0$ & 0.29 & 0.17 & 0.32 & -0.15 & 0.73 \\
\hline & & $6.1-6.5$ & -0.08 & 0.17 & 0.97 & -0.51 & 0.36 \\
\hline & & $6.6-7.0$ & -0.20 & 0.17 & 0.63 & -0.63 & 0.23 \\
\hline & \multirow[t]{3}{*}{$5.6-6.0$} & $5.0-5.5$ & -0.29 & 0.17 & 0.32 & -0.73 & 0.15 \\
\hline & & $6.1-6.5$ & -0.37 & 0.15 & 0.08 & -0.77 & 0.03 \\
\hline & & $6.6-7.0$ & $-0.49^{*}$ & 0.15 & 0.01 & -0.89 & -0.09 \\
\hline & \multirow[t]{3}{*}{$6.1-6.5$} & $5.0-5.5$ & 0.08 & 0.17 & 0.97 & -0.36 & 0.51 \\
\hline & & $5.6-6.0$ & 0.37 & 0.15 & 0.08 & -0.03 & 0.77 \\
\hline & & $6.6-7.0$ & -0.12 & 0.15 & 0.86 & -0.51 & 0.27 \\
\hline & \multirow[t]{3}{*}{$6.6-7.0$} & $5.0-5.5$ & 0.20 & 0.17 & 0.63 & -0.23 & 0.63 \\
\hline & & $5.6-6.0$ & $0.49^{*}$ & 0.15 & 0.01 & 0.09 & 0.89 \\
\hline & & $6.1-6.5$ & 0.12 & 0.15 & 0.86 & -0.27 & 0.51 \\
\hline \multirow[t]{12}{*}{ AUSTMS } & \multirow[t]{3}{*}{$5.0-5.5$} & $5.6-6.0$ & -0.34 & 0.16 & 0.17 & -0.76 & 0.09 \\
\hline & & $6.1-6.5$ & $-0.60^{*}$ & 0.16 & 0.00 & -1.02 & -0.18 \\
\hline & & $6.6-7.0$ & $-0.95^{*}$ & 0.16 & 0.00 & -1.37 & -0.54 \\
\hline & \multirow[t]{3}{*}{$5.6-6.0$} & $5.0-5.5$ & 0.34 & 0.16 & 0.17 & -0.09 & 0.76 \\
\hline & & $6.1-6.5$ & -0.26 & 0.15 & 0.29 & -0.65 & 0.12 \\
\hline & & $6.6-7.0$ & $-0.61 *$ & 0.15 & 0.00 & -1.00 &,- 23 \\
\hline & \multirow[t]{3}{*}{$6.1-6.5$} & $5.0-5.5$ & $0.60 *$ & 0.16 & 0.00 & 0.18 & 1,02 \\
\hline & & $5.6-6.0$ & 0.26 & 0.15 & 0.29 & -0.12 & 0.65 \\
\hline & & $6.6-7.0$ & -0.35 & 0.14 & 0.07 & -0.72 & 0.02 \\
\hline & \multirow[t]{3}{*}{$6.6-7.0$} & $5.0-5.5$ & $0.95^{*}$ & 0.16 & 0.00 & 0.54 & 1.37 \\
\hline & & $5.6-6.0$ & $0.61^{*}$ & 0.15 & 0.00 & 0.23 & 1.00 \\
\hline & & $6.1-6.5$ & 0.35 & 0.14 & 0.07 & -0.02 & 0.72 \\
\hline \multirow[t]{12}{*}{ STVISM } & \multirow[t]{3}{*}{$5.0-5.5$} & $5.6-6.0$ & -0.17 & 0.16 & 0.74 & -0.59 & 0.25 \\
\hline & & $6.1-6.5$ & $-0.56^{*}$ & 0.16 & 0.00 & -0.97 & -0.14 \\
\hline & & $6.6-7.0$ & $-0.94 *$ & 0.16 & 0.00 & -1.35 & -0.53 \\
\hline & \multirow[t]{3}{*}{$5.6-6.0$} & $5.0-5.5$ & 0.17 & 0.16 & 0.74 & -0.25 & 0.59 \\
\hline & & $6.1-6.5$ & $-0.39 *$ & 0.15 & 0.04 & -0.77 & -0.01 \\
\hline & & $6.6-7.0$ & $-0.77^{*}$ & 0.15 & 0.00 & -1.15 & -0.39 \\
\hline & \multirow[t]{3}{*}{$6.1-6.5$} & $5.0-5.5$ & $0.56^{*}$ & 0.16 & 0.00 & 0.14 & 0.97 \\
\hline & & $5.6-6.0$ & $0.39^{*}$ & 0.15 & 0.04 & 0.01 & 0.77 \\
\hline & & $6.6-7.0$ & $-0.38^{*}$ & 0.14 & 0.04 & -0.75 & -0.01 \\
\hline & \multirow[t]{3}{*}{$6.6-7.0$} & $5.0-5.5$ & $0.94^{*}$ & 0.16 & 0.00 & 0.53 & 1.35 \\
\hline & & $5.6-6.0$ & $0.77 *$ & 0.15 & 0.00 & 0.39 & 1.15 \\
\hline & & $6.1-6.5$ & $0.38^{*}$ & 0.14 & 0.04 & 0.01 & 0.75 \\
\hline
\end{tabular}


Hrvatska revija za rehabilitacijska istraživanja 2020, Vol 56, br. 2, str. 1-18

\begin{tabular}{|c|c|c|c|c|c|c|c|}
\hline \multirow[t]{12}{*}{ STVSM } & \multirow[t]{3}{*}{$5.0-5.5$} & $5.6-6.0$ & 0.10 & 0.16 & 0.92 & -0.32 & 0.53 \\
\hline & & $6.1-6.5$ & $-0.47^{*}$ & 0.16 & 0.02 & -0.88 & -0.06 \\
\hline & & $6.6-7.0$ & $-0.76^{*}$ & 0.16 & 0.00 & -1.17 & -0.34 \\
\hline & \multirow[t]{3}{*}{$5.6-6.0$} & $5.0-5.5$ & -0.10 & 0.16 & 0.92 & -0.53 & 0.32 \\
\hline & & $6.1-6.5$ & $-0.57 *$ & 0.15 & 0.00 & -0.95 & -0.19 \\
\hline & & $6.6-7.0$ & $-0.86^{*}$ & 0.15 & 0.00 & -1.24 & -0.48 \\
\hline & \multirow[t]{3}{*}{$6.1-6.5$} & $5.0-5.5$ & $0.47 *$ & 0.16 & 0.02 & 0.06 & 0.88 \\
\hline & & $5.6-6.0$ & $0.57 *$ & 0.15 & 0.00 & 0.19 & 0.95 \\
\hline & & $6.6-7.0$ & -0.29 & 0.14 & 0.19 & -0.66 & 0.08 \\
\hline & \multirow[t]{3}{*}{$6.6-7.0$} & $5.0-5.5$ & $0.76^{*}$ & 0.16 & 0.00 & 0.34 & 1.17 \\
\hline & & $5.6-6.0$ & $0.86^{*}$ & 0.15 & 0.00 & 0.48 & 1.24 \\
\hline & & $6.1-6.5$ & 0.29 & 0.14 & 0.19 & -0.08 & 0.66 \\
\hline \multirow[t]{12}{*}{ RAN } & \multirow[t]{3}{*}{$5.0-5.5$} & $5.6-6.0$ & -0.30 & 0.17 & 0.27 & -0.73 & 0.13 \\
\hline & & $6.1-6.5$ & 0.16 & 0.16 & 0.77 & -0.26 & 0.58 \\
\hline & & $6.6-7.0$ & $0.53^{*}$ & 0.16 & 0.01 & 0.11 & 0.95 \\
\hline & \multirow[t]{3}{*}{$5.6-6.0$} & $5.0-5.5$ & 0.30 & 0.17 & 0.27 & -0.13 & 0.73 \\
\hline & & $6.1-6.5$ & $0.46^{*}$ & 0.15 & 0.01 & 0.07 & 0.84 \\
\hline & & $6.6-7.0$ & $0.83 *$ & 0.15 & 0.00 & 0.45 & 1.22 \\
\hline & \multirow[t]{3}{*}{$6.1-6.5$} & $5.0-5.5$ & -0.16 & 0.16 & 0.77 & -0.58 & 0.26 \\
\hline & & $5.6-6.0$ & $-0.46^{*}$ & 0.15 & 0.01 & -0.84 & -0.07 \\
\hline & & $6.6-7.0$ & 0.38 & 0.15 & 0.05 & 0.00 & 0.75 \\
\hline & \multirow[t]{3}{*}{$6.6-7.0$} & $5.0-5.5$ & $-0.53^{*}$ & 0.16 & 0.01 & -0.95 & -0.11 \\
\hline & & $5.6-6.0$ & $-0.83^{*}$ & 0.15 & 0.00 & -1.22 & -0.45 \\
\hline & & $6.1-6.5$ & -0.38 & 0.15 & 0.05 & -0.75 & 0.00 \\
\hline \multirow[t]{12}{*}{ REWPH } & \multirow[t]{3}{*}{$5.0-5.5$} & $5.6-6.0$ & -0.29 & 0.16 & 0.26 & -0.69 & 0.12 \\
\hline & & $6.1-6.5$ & $-0.66^{*}$ & 0.15 & 0.00 & -1.06 & -0.27 \\
\hline & & $6.6-7.0$ & $-1.22 *$ & 0.15 & 0.00 & -1.61 & -0.82 \\
\hline & \multirow[t]{3}{*}{$5.6-6.0$} & $5.0-5.5$ & 0.29 & 0.16 & 0.26 & -0.12 & 0.69 \\
\hline & & $6.1-6.5$ & $-0.38^{*}$ & 0.14 & 0.04 & -0.74 & -0.01 \\
\hline & & $6.6-7.0$ & $-0.93 *$ & 0.14 & 0.00 & -1.29 & -0.57 \\
\hline & \multirow[t]{3}{*}{$6.1-6.5$} & $5.0-5.5$ & $0.66^{*}$ & 0.15 & 0.00 & 0.27 & 1.06 \\
\hline & & $5.6-6.0$ & $0.38^{*}$ & 0.14 & 0.04 & 0.01 & 0.74 \\
\hline & & $6.6-7.0$ & $-0.55^{*}$ & 0.14 & 0.00 & -0.91 & -0.20 \\
\hline & \multirow[t]{3}{*}{$6.6-7.0$} & $5.0-5.5$ & $1.22 *$ & 0.15 & 0.00 & 0.82 & 1.61 \\
\hline & & $5.6-6.0$ & $0.93 *$ & 0.14 & 0.00 & 0.57 & 1.29 \\
\hline & & $6.1-6.5$ & $0.55^{*}$ & 0.14 & 0.00 & 0.20 & 0.91 \\
\hline \multirow[t]{12}{*}{ VOCWC } & \multirow[t]{3}{*}{$5.0-5.5$} & $5.6-6.0$ & -0.04 & 0.17 & 0.99 & -0.47 & 0.39 \\
\hline & & $6.1-6.5$ & $-0.63 *$ & 0.16 & 0.00 & -1.05 & -0.21 \\
\hline & & $6.6-7.0$ & $-0.67 *$ & 0.16 & 0.00 & -1.09 & -0.25 \\
\hline & \multirow[t]{3}{*}{$5.6-6.0$} & $5.0-5.5$ & 0.04 & 0.17 & 0.99 & -0.39 & 0.47 \\
\hline & & $6.1-6.5$ & $-0.59 *$ & 0.15 & 0.00 & -0.98 & -0.21 \\
\hline & & $6.6-7.0$ & $-0.63 *$ & 0.15 & 0.00 & -1.01 & -0.24 \\
\hline & \multirow[t]{3}{*}{$6.1-6.5$} & $5.0-5.5$ & $0.63^{*}$ & 0.16 & 0.00 & 0.21 & 1.05 \\
\hline & & $5.6-6.0$ & $0.59 *$ & 0.15 & 0.00 & 0.21 & 0.98 \\
\hline & & $6.6-7.0$ & -0.04 & 0.15 & 0.99 & -0.41 & 0.34 \\
\hline & \multirow[t]{3}{*}{$6.6-7.0$} & $5.0-5.5$ & $0.67 *$ & 0.16 & 0.00 & 0.25 & 1.09 \\
\hline & & $5.6-6.0$ & $0.63^{*}$ & 0.15 & 0.00 & 0.24 & 1.01 \\
\hline & & $6.1-6.5$ & 0.04 & 0.15 & 0.99 & -0.34 & 0.41 \\
\hline
\end{tabular}

* The difference between the arithmetic means was statistically significant if $\mathrm{p}<0.05$. 
Table 6. Eigenvalue ( $\lambda$ ), the percentage of explained variance of each factor (\%), and cumulative percentage $(F)$

\begin{tabular}{|l|c|c|c|}
\hline \multirow{2}{*}{ Component } & \multicolumn{3}{|c|}{ Rotation Sums of Squared Loadings } \\
\cline { 2 - 4 } & $\boldsymbol{\lambda}$ & $\begin{array}{c}\text { \% of } \\
\text { variance }\end{array}$ & F \% \\
\hline 1 & 6.398 & 37.635 & 37.635 \\
\hline 2 & 1.243 & 7.309 & 44.944 \\
\hline 3 & 1.049 & 6.172 & 51.116 \\
\hline 4 & 1.005 & 5.911 & 57.027 \\
\hline
\end{tabular}

Table 7. Structure of factor matrices by oblimin rotation

\begin{tabular}{|l|c|c|c|c|}
\hline & \multicolumn{5}{|c|}{ Component } \\
\hline & $\mathbf{1}$ & $\mathbf{2}$ & $\mathbf{3}$ & $\mathbf{4}$ \\
\hline DELPH & 0.855 & & & \\
\hline DELSY & 0.788 & & & \\
\hline REWPH & 0.745 & & & \\
\hline PHONANAL & 0.717 & & & \\
\hline AUSTMD & 0.701 & & & \\
\hline AUSTMS & 0.590 & & & \\
\hline STAMVS & 0.566 & 0.387 & & \\
\hline IDFSOUND & 0.526 & & & \\
\hline RAN & -0.429 & & & \\
\hline SYNSYL & & 0.733 & & \\
\hline PHONDIS & & 0.556 & & 0.320 \\
\hline IDRHYM & & 0.542 & & \\
\hline ANALSYL & & & 0.799 & \\
\hline VOCWC & & & 0.431 & \\
\hline STVISM & & & & 0.818 \\
\hline VISDISA & & & & 0.650 \\
\hline STVSM & & & & 0.600 \\
\hline
\end{tabular}

factor of metaphonology. It includes phonological processing abilities: phonological awareness, verbal short-term memory, and rapid automatic naming.

The second factor explained $7.3 \%$ of the variance and was most saturated by syllable synthesis, phoneme discrimination, and identifying rhymes. The factor, named perceptual linguistic structure, expresses macro-linguistic structure (syllable, rhymes) and discrimination of words that sound similar.

The third factor explained $6.2 \%$ of the variance. It was most saturated by syllable analysis, vocabulary and word comprehension. The factor was named vocabulary because both variables are connected to word comprehension.
The fourth factor explained 5.9\% of the variance and was most saturated by short-term visual memory, visual discrimination accuracy, and shortterm visual-spatial memory. Therefore this factor was named visual processing.

\section{DISCUSSION}

Our results confirm that children before the sixth year of age are successful on tests that measure lower-level phonological abilities. They can memorise smaller units of symbols presented visually or aurally, and they can discriminate visually similar symbols, but they have problems discriminating symbols that differ in orientation. We found that before the seventh year of age, children develop most of the higher-level phonological abilities and can memorise large units of symbols presented visually or aurally. It is important to note that children aged 7 years have not yet fully developed higher-level phonological abilities and are still developing working memory. The subtest of removing a phoneme or syllable from a word without meaning checks the highest level of phonological awareness when working memory functions. The subtest of auditory short-term memory for sentences requires that children have effective verbal working memory. B. Jurišić (2001) explains that the ability to remove a phoneme or a syllable from a word without meaning is rarely found among children who cannot read. Jerman (2000) argues that the ability to remove a phoneme/syllable from a meaningless word is too difficult for children aged five to six. He points out that it would be appropriate to evaluate syllable and phoneme deletion from the age of seven years, when cognitive developmental theory holds that children are capable of more sophisticated phonological processing information. Lytinen et al. (2015) explain that lower-level phonological awareness does not cause major problems for children, but they have difficulties in tasks that require higher-level phonological awareness with appropriate working memory. A survey (Chacko \& Kumaraswamy, 2015) showed that six-year-old children are more sensitive to larger language units and less sensitive to smaller ones. Eight-year-old children are sensitive to both smaller and larger language units; eight-year-old children are more successful than 
five-year-old children at deleting a phoneme/syllable from a meaningless word (Varghese, 2012). Bentin, Hammer and Cahan (2008) found that children aged six to seven have more developed phonological awareness than children aged five to six. Furthermore, they found out that there were no significant differences in development of phonological awareness between children aged six to seven and children aged seven to eight. The authors therefore conclude that phonological awareness develops by the age of seven. Many researchers (Chacko \& Kumaraswamy, 2015; Jerman, 2000; Jurišić, 200; Lyytinen, 2015; Pečjak, 1999) agree that preliteracy competences develop intensely between the ages of five and seven years, and that their development, especially the development of more advanced abilities (e.g. higher-level phonological awareness and working memory) continues beyond the age of seven.

The latent structure of preliteracy competence in children aged five to seven is determined by four factors: metaphonology, perceptual language structure, vocabulary, and visual processing. Factor analysis confirms that verbal memory is important for identifying, analysing, and manipulating the smallest linguistic structure, phonemes. On the other hand, a well-developed phonological awareness helps children memorise verbal material. The first factor includes phonological processing, which encompasses higher-level phonological abilities, verbal short-term memory, and rapid recall of verbal material from long-term memory. We found that higher-level phonological awareness at the level of phoneme recognition and manipulation is strongly associated with auditory short-term memory and recall of verbal information. Baddeley et al. (2009) explain that storage and retrieval of verbal information are fundamental for an effective phonological loop. Our study found that lower-level phonological abilities are less correlated with higher-level phonological abilities and verbal working memory. Lover-level phonological abilities do not include several complicated processes that are involved in higher-level phonological abilities and working memory. The second factor includes melody and the sequence of phonemes. The child hears whether there are phonemes or sequences of phonemes that are the same or different, and he or she combines parts of words (syllables, rhymes) into new words. The third factor can be explained by the fact that children with better vocabulary have more linguistic knowledge, which they have also learned through statistical learning of sequences of phonemes or syllables. The last factor captures skills in storing and refreshing non-verbal information and in discriminating symbols. Our analysis confirms that the phonological loop and the visual-spatial scratchpad are separate components of working memory.

Many authors (Arina et al.., 2015; Christoper et al.., 2015; Georgiou et al., 2016) emphasise that working memory for verbal material and phonological awareness play a unique role in predicting later reading success. Baddeley (2009) explains in a model of working memory that phonological awareness, verbal memory, and the rapid recall of verbal information are important for effective functioning of the phonological loop. Henry (2012) explains that individuals who can retrieve information faster from verbal memory can process more information in phonological storage than those who retrieve information more slowly. Sousa (2005) emphasises that phonological awareness is fundamental for the development and use of verbal memory, i.e. for the ability to use and store the representations of written words. However, a properly developed phonological awareness and working memory enable the reader to understand not only sentences but also paragraphs and chapters. S. Arina et al. (2015) say that verbal memory strengthens decoding of words on a phonological level. It has a unique role in maintaining grapheme-phoneme connections. Poor readers find it difficult to retain verbal information in working memory (Tilanus et al., 2013). Savage et al. (2007) have demonstrated that tasks that measure auditory short-term memory (specifically, tasks involving series of sentences in which the child needs to say whether they are true, and the child needs to repeat the last words of each sentence) are a strong predictor of reading for typical and atypical readers. Furthermore, they found that these tasks correlate more with phonological awareness than with other measurements of central executive functioning. Individuals who have reading difficulties (especially problems with decoding) have problems 
with working memory, phonological awareness, and recall of verbal information (Tilanus et al., 2013). Lei et al. (2011) point out that deficits in phonological processing, which include phonological awareness, phonological memory, and rapid automatic naming, are the most important predictors of reading difficulties. Lin et al. (2016) have demonstrated that visual-spatial abilities in kindergarten are associated with reading performance in first, second and third grade of primary school. M. Kibby et al. (2015) emphasise that reading difficulties are related to visual processing problems. Kavale and Fornes (2000) argue that visual memory and visual discrimination are the best predictor of general reading ability. They found that individuals with reading difficulties have problems distinguishing visually similarly symbols and with memorising sequences of visual symbols. J. Caroll et al. (2015) found through longitudinal study that all weak readers in their sample showed difficulties on at least one preliteracy ability before entering school. The authors thus concluded that there is no single preliteracy ability that predicts reading difficulties.

Factor analysis explained nearly $60 \%$ of the variance in our study. Numerous studies report that the links between preliteracy abilities are influenced by numerous factors, such as intellectual abilities (Jenko, 2016; Jerman, 2000), emotional-motivational factors (Ghanbachi \& Rastegar, 2014; Pečjak, 2010; Pečjak \& Gradišar, 2015), socio-cultural factors (Heckman, 2008; Košak Babuder, 2012; Scheicher, 2014), attention (Finn et al., 2013; Ozbič et al., 2012; Shaywitz and Shaywitz, 2008) and executive functions (Booth, Boyle \& Kelly, 2010; Hudoklin, 2016; Locascio, Mahone, Eason, \& Cutting, 2010).
At the theoretical introduction, we presented preliteracy abilities which, according to numerous authors (Catts, 2017; Carroll et al. 2016; Scarborough, 2001; Wagner and Torgesen, 1987), have an impact on success in learning to read. As expected, our results show that children aged 5 to 7 years show the greatest differences in the phonological processing abilities (phonological awareness, phonological short-term memory and rapid automatic naming). Children aged 5 to 6 years have already developed most of the lower-level phonological abilities (e. g. syllable analysis/synthesis, rhyme identification, phoneme discrimination) and can memorise a smaller set of symbols presented aurally or visually. Children aged 6 to 7 years become more aware of smaller language units (phonemes) and can memorise larger units of symbols presented visually or aurally. It is important to note that the identified factors explain the latent structure of preliteracy competence and indicate the following areas of work: phonological awareness, verbal short-term memory, visual processing (discrimination and short-term memory) and vocabulary knowledge. Most children need phonological awareness exercises and the development of memory abilities. We need to adapt these exercises to the level of development of preliteracy abilities of each age group of children. We need to choose exercises appropriate difficulty to encourage children to a higher level of development of preliteracy abilities. Most of the problems in word recognition can be explain by phonological processing abilities, but some children can have difficulties in reading because of visual processing deficits or poor vocabulary. 


\section{REFERENCES}

Al Otaiba, S., \& Fuchs, D. (2006). Who Are the Young Children for Whom Best Practices in Reading Are Ineffective? An Experimental and Longitudinal Study. Journal of Learning Disabilities, 39(5), 414-431.

Arina, S., Gathercole, S., \& Stella, G. (2015). The role of the working memory in the early phases of learning to read. Applied Psychology Bulletin, 64 (273), 31-52.

Baddeley, A., Eysenck, M. W., \& Anderson M. C. (2009). Memory. New York: Psychology Press.

Batson - Magnuson, L. (2010). Phonological and Non-Phonological Language Skills as Predictors of Early Reading Performance. Pro Quest LLC Ph.D. Dissertation, University of Medicine and Dentistry of New Jersey.

Bentin, S., Hammer, R., \& Cahan, S. (1991). The effects of aging and first-grade schooling on the development of phonological awareness. Psychological Science, 2, 271-274.

Booth, J. N., Boyle, J. \& Kelly, S. (2010) Do tasks make a difference? Accounting for heterogeneity of performance of children with reading difficulties on tasks of executive function: findings from a meta-analysis. British Journal of Developmental Psychology, 28 (1), 133-176.

Catts, H. W. (2017). Early identification of reading disabilities. In K. Cain, D. L. Compton \& R. K. Parrila (Eds.), Theories of Reading Development (pp. 311-332). Amsterdam: John Benjamins Publishing Company.

Catts, H. W. \& Adolf, S. (2011). Phonological and other language deficits associated with dyslexia. In S. Brady, D. Braze in C. A. Flower (Eds.), Explaning individual differences in reading: Theory and evidence (str. 137-151). New York: Psychological Press.

Carroll, M. J., Solity, J., \& Shapiro, R. L. (2016). Predicting dyslexia using prereading skills: the role of sensorimotor and cognitive abilities. Journal of child psychology and psychiatry, 57 (6), 750-758.

Chacko, N. \& Kumaraswamy, S. (2015). A few phonological awareness skills in 6-8 year old typically developing English speaking children. Language in India, 15(10), 182-209.

Christopher, M. E., Hulslander, J., Byrne, B., Samuelsson, S., Keenan, J. M., Pennington, B. et al. (2015). Genetic and environmental etiologies of the longitudinal relations between prereading skills and reading. Child Development, $86,342-361$.

Denckla M. B., Rudel R. G. (1976). Rapid 'automatized'naming (RAN): Dyslexia differentiated from other learning disabilities. Neuropsychologia. 14(4), 471-479.

Ehri, L. C. (2017). Ortographic mapping and literacy development revisited. In K. Cain, D. L. Compton \& R. K. Parrila (Eds.), Theories of Reading Development (pp. 127-146). Amsterdam: John Benjamins Publishing Company.

Finn, A. S., Hudson Kam, C. L., Ettlinger, M., Vytlacil, J. \& Desposito, M. (2013). Learning language with the wrong neural scaffolding: the cost of neural commitment to sounds. Frontiers in Systems Neuroscience, 7(85), 1-15.

Gathercole, S. E., \& Adams, A.-M. (1994). Children‘s phonological working memory: Contributions of long-term knowledge and rehearsal. Journal of Memory and Language, 33(5), 672-688.

Georgiou G. \& Parrila R. (2013). Rapid automatized naming and reading: a review. In Swanson H. L., Harris K. R., Graham S., (Eds.), Handbook of Learning Disabilities (pp. 169-185). New York: Guilford press.

Georgiou, G. K., Aro, M., Lia, C. H., \& Parrilla, R. (2016). Modeling the relationship between rapid automatized naming and literacy skills across languages varying in orthographic consistency. Journal of Experimental Child Psychology, 143, 48-65.

Ghabanchi, Z. \&b Rastegar, R. (2014). The correlation of IQ and emotional intelligence with reading comprehension. Reading Matrix: An international online journal, 14(2), 135-144.

Goswami, U., \& Bryant, P. (1990). Essays in developmental psychology series. Phonological skills and learning to read. Lawrence Erlbaum Associates, Inc.

Heckman, J. J. (2008). Schools, skills, and synapses. Economic inquiry, 46(3), 289-324. 
Henry, L. (2012). The development of working memory in children. California: Thousand Oaks.

Hogan, T. P. Catts, H. W \& Little, T. D. (2005). The Relationship Between Phonological Awareness and Reading: Implications for the Assessment of Phonological Awareness. Language, speech, and hearing services in schools, $36,285-293$.

Hudoklin, M. (2015). Težave na področju izvršilnih funkcij pri učencih z bralno-napisovalnimi učnimi težavami - kako lahko pomagamo? In Z. Pavlović (Ed.), Zbornik strokovnega simpozija ob 60-letnici Svetovalnega centra: 60 let podpore pri vzgoji, učenju in odraščanju (pp. 78-93). Ljubljana: Svetovalni center za otroke, mladostnike in starše.

Jenko, N. (2015). Struktura in razvoj bralne pismenosti učencev v prilagojenjem programu z nižjim izobrazbenim standardom (Doktorska disertacija). Ljubljana: Univerza v Ljubljani, Pedagoška fakulteta.

Jerman, J. (2000). Ugotavljanje razvoja fonološkega zavedanja pri predšolskih otrocih. (Doktorska disertacija). Ljubljana: Univerza v Ljubljani, Pedagoška fakulteta.

Jurišič, B. (2001). Ugotavljanje zgodnjih bralnih zmožnosti otrok pred vstopom v osnovno šolo (Doktorska disertacija). Ljubljana: Univerza v Ljubljani, Pedagoška fakulteta.

Kavale, K. A. \& Forness, S. R. (2000). What definitions of learning disability say and don't say: A critical analysis. Journal of Learning Disabilities, 33, 239-256.

Kendeou, P., van den Broek, P., White, M. J., \& Lynch, J. (2009). Predicting Reading Comprehension in Early Elementary School: The Independent Contributions of Oral Language and Decoding Skills. Journal of Educational Psychology 101(4), 765-778

Kibby, M. Y., Dyer, S. M., Vadnais, S. A., Jagger, A. C., Casher, G. A., \& Stacy, M. (2015). Visual processing in reading disorders and attention-deficit/hyperactivity disorder and its contribution to basic reading ability. Frontiers psychology, 6 (1635).

Kim Y. S. \& Wagner R. K. (2015). Text (Oral) Reading fluency as a construct in reading development: an investigation of its mediating role for children from grades 1 to 4. Scientific studies of reading, 19, 224-242.

Kirby, J. R., Georgiou, G. K., Martinussen, R., \& Parrila, R. (2010). Naming speed and reading: From prediction to instruction. Reading Research Quarterly, 45, 341-362.

Košak Babuder, M. (2012). Bralno razumevanje in razvoj branja za učenje pri otrocih iz manj spodbudnega okolja zaradi revščine (Doktorska disertacija). Ljubljana: Univerza v Ljubljani, Pedagoška fakulteta.

Landerl, K. et al. (2013). Predictors of developmental dyslexia in European orthographies with varying complexity. Journal of Child Psychology and Psychiatry, 54(6), 686-694.

Lei, L. et al. (2011). Developmental trajectories of reading development and impairment from ages 3 to 8 years in Chinese children. Journal of Child Psychology and Psychiatry 52(2), 212-220.

Lervåg, A. \& Hulme, C. (2009). Rapid Automatized Naming (RAN) Taps a Mechanism That Places Constraints on the Development of Early Reading Fluency. Psychological Science, 20(8), https://doi.org/10.1111\%2Fj.14679280.2009.02405.x

Lin, D., Sun, H., \& Zhang, X. (2016). Bidirectional relationship between visual spatial skill and Chinese character reading in Chinese kindergartners: A cross-lagged analysis. Contemporary Educational Psychology, 46, 94-100.

Locascio, G., Mahone, E. M., Eason, S. H. \& Cutting, L. E. (2010). Executive dysfunction among children with reading comprehension deficits. Journal of learning disabilities, 43(5), 441-54.

Lytinen, H., Erskine, J., Hamalainen, J., \& Torppa, M. (2015). Early identification and prevention: Hightlights from the Jyväskylä longitudinal study of dyslexia. Developmental dyslexia, 2(4), 330-338.

Magajna, L., Kavkler, M., Čačinovič Vogrinčič, G., Pečjak, S. in Bregar Golobič, K. (2008). Učne težave v osnovni šoli: koncept dela. Ljubljana: Zavod RS za šolstvo.

Mann V. A. \& Liberman I.Y. (1984). Phonological awareness and verbal short-term memory. Journal of learning disabilities. 17(10), 592-599. 
Melby - Lervag, M., Halaas Lyster, S. A., \& Hulme, C. (2012). Phonological skills and their role in learning to read: A meta-analytic review. Psychological Bulletin, 138(2), 322-352.

Norton E. S. \& Wolf M. (2012). Rapid automatized naming (RAN) and reading fluency: Implications for understanding and treatment of reading disabilities. Annual review of psychology, 63, 427-452.

Ortiz, R., Estevez, A., Muneton, M., \& Dominguez, C. (2014). Visual and auditory perception in preschool children at risk for dyslexia. Research in developmental disabilities, 35, 2673-2680.

Ozernov-Palchik, O., Norton, E. S., Sideridis, G., Beach, S. D., Wolf, M., Gabrieli, D. E., \& Gaab N. (2016). Longitudinal stability of pre-reading skill profiles of kindergarten children: implications for early screening and theories of reading, Developmental Science, 20(5), https://doi.org/10.1111/desc.12471

Ozbič, M., Kogovšek, D., Zver, P., Novšak Brce, J. \& Vališer, A. (2012). Zgodnje prepoznavanje morebitnih učnih težav pred vstopom v šolo z vprašalnikom za vzgojitelje in učitelje. Pogledi na vodenje, 2(10), 23-37.

Pan, J., McBride - Chang, C., Shu, H., Liu, H., Zhang, Y., \& Li, H. (2011). What is the naming? A 5 year longitudinal study of early rapid naming and phonological sensitivity in relation to subsequent reading skills in both native Chinese and English as a second language. Journal of Educational Psychology, 103(4), 897-908.

Parrila, R. K. \& Protopapas, A. (2017). Dyslexia and word reading problems. In K. Cain, D. L. Compton in R. K. Parrila (Eds.), Theories of Reading Development (str. 333-358). Amsterdam: John Benjamins Publishing Company.

Pečjak, S. (1996). Kako do boljšega branja. Tehnike in metode za izboljšanje bralne učinkovitosti. Ljubljana: Zavod Republike Slovenije za šolstvo in šport.

Pečjak, S. (1999). Osnove psihologije branja: spiralni model kot oblika razvijanja bralnih sposobnosti učencev. Ljubljana: Znanstveni inštitut Filozofske fakultete.

Pečjak, S. (2010). Osnove bralne pismenosti. Od teorije k praksi. Ljubljana: Znanstveni inštitut Filozofske fakultete v Ljubljani.

Pečjak, S. \& Gradišar A. (2015). Bralne učne strategije. Ljubljana: Zavod Republike Slovenije za šolstvo.

Savage, R. Lavers, N., \& Pillay, V. (2007). Working Memory and Reading Difficulties: What We Know and What We Don't Know About the Relationship. Educational Psychology Review, 19(2), 185-221.

Scarborough H. S. (1998). Predicting the future achievement of second graders with reading disabilities: Contributions of phonemic awareness, verbal memory, rapid naming, and IQ. Annals of Dyslexia. 48(1):115-136.

Scalisi, T. G., Pelagaggi D., Fanini, S., Desimoni, M. \& Romano, L. (2009). PAC-SI/Prove di abilità cognitive per la scuola dell'infanzia. Edizioni Infantiae. Retrived from http://www.infantiae.org/pacsi_cons_fono.asp.

Scarborough, H. S. (2001). Connecting early language and literacy to later reading (dis)abilities: Evidence, theory, and practice. In S. Neuman \& D. Dickinson (Eds.), Handbook for research in early literacy (pp. 97-110). New York: Guilford Press.

Schleicher, A. (2014). Equity, Excellence and Inclusiveness in Education PolIcy lEssons from Around thE World. Retrived from https://www.ucy.ac.cy/equality/documents/Articles-Material/OECD_2014_Report.pdf.

Shaywitz, S. E. \& Shaywitz, B. A. (2008). Paying attention to reading: The neurobiology of reading and dyslexia. Development and Psychopathology, 20, 1329-1349.

Siegel L. S. \& Linder B. A. (1984). Short-term memory processes in children with reading and arithmetic learning disabilities. Developmental Psychology, 20(2), 200-217.

Singleton, C. H., Thomas, K. V. \& Leedale, R. C. (2003). Lucid COPS. Cognitive profiling system. Teachers manual. Third edition. Beverley: LucidResearchLtd.

Sousa, D. A. (2005). How the brain learns to read. California: Thousand Oaks.

Stanovich K. E., Cunningham A. E., \& Feeman D. J. (1984). Relation between early reading acquisition and word decoding with and without context: A longitudinal study of first-grade children. Journal of Educational 
Psychology.76(4), 668-693.

Tilanus, A. T., E., Segers, E., \& Verhoven, L. (2013). Diagnostic profiles of children with developmental dyslexia in transparent orthography. Research in Developmental Disabilities, 34, 4194-4202.

Torgesen J. K., Wagner R. K., Rashotte C. A., Burgess S., \& Hecht S. (1997). Contributions of phonological awareness and rapid automatic naming ability to the growth of word-reading skills in second-to fifth-grade children. Sci. Stud. Read. 1, 161-185.

Torgesen, J. K. \& Mathes, P. G. (2000). A basic guide to understanding, assessing and teaching phonological awareness. Austin, TX: PRO-ED.

Torppa, M., Georgiou, G., Salmi, P., Eklund, K. \& Lyytinen, H. (2013). Examining the double-deficit hypothesis in an orthographically consistent language. Scientific Studies of Reading, 16(4), 287-315.

Varghese, M. (2012). A linguistic minority student's discursive framing of agency and structure. V Y. Kanno in L. Harklau (ur.), Linguistic minority immigrants go to college: Preparation, access, and persistence (pp. 148-163). New York: Routledge.

Wagner, R. K., \& Torgesen, J. K. (1987). The nature of phonological processing and its causal role in the acquisition of reading skills. Psychological Bulletin, 101(2), 192-212.

Walcott, C. M., Scheemaker, A., \& Bielski, K. (2010). A longitudinal investigation of inattention and preliteracy development. Journal of attention disorders, 14(1), 79-85.

Weedon, C., Reid, G., Kovačič, D., Grobler, M., Košak Babuder, M., Lipec Stopar, M., Magajna, L., Ozbič, M. \& in Pulec Lah, S. (2009). Profil ocene posebnih potreb: priročnik za uporabo: (računalniško podprt diagnostični preizkus z izdelavo profila: 5-14 let). Ljubljana: Center za psihodiagnostična sredstva.

Woodrome, S. E. \& Johnson, K. E. (2009). The role of visual discrimination in the learning to read process. Reading and Writing, 22, 117-131.

Ziegler, J. C., \& Goswami, U. (2005). Reading Acquisition, Developmental Dyslexia, and Skilled Reading Across Languages: A Psycholinguistic Grain Size Theory. Psychological Bulletin, 131(1), 3-29.

Ziegler, J. C., Betrand, D., Torth, D., Csepe, V. Reis, A., Faisca, L., \& Blomert, L. (2010). Ortographic depth and its impact on universal predictors of reading: A cross-language investigation. Psychological Science, 21, 551-559. 